RESEARCH PAPER

\title{
Cooperation and control: the Tobacco Institute of Australia
}

\section{S M Carter}

Tobacco Control 2003;12(Suppl III):iii54-iii60

\begin{abstract}
Objective: To describe the history of the Tobacco Institute of Australia (TIA), particularly regarding connections between local and international cigarette manufacturers and tobacco organisations.

Design: Analysis of 4541 industry documents from the world wide web.

Results: From 1978 to 1983 the TIA built strong international networks via ICOSI/INFOTAB and the US Tobacco Institute, and defended existing industry freedoms. 1983 to 1989 was the TIA's aggressive heyday, led primarily by John Dollisson. From 1989 to 1994, following the decision in Australian Federation of Consumer Organisations vs TIA, local and international industry lawyers assumed control. Between 1994 and 1997 a brief revival led into decline and then dissolution, as previously common ground became commercially competitive issues for the manufacturers. The TIA facilitated interconnectedness: between local manufacturers; via individuals who played multiple roles; to international tobacco organisations; through the industry's local and international counsel; and by acting as a conduit for information.

Conclusion: The local tobacco industry was comprehensively informed on issues including smoking and health, and connected to the international industry, via the TIA. The manufacturers were closely involved in the TIA's activities, and cooperated through the TIA in a manner detrimental to Australian consumers. The TIA's conduct was the responsibility of local and international manufacturers and their counsel.
\end{abstract}

Stacy M Carter, School of Public Health, Room 128A Building A27, University of Sydney NSW 2006,

Australia; carters@

health.usyd.edu.au
$\mathrm{T}$ his paper, arising from a project designed to provide evidence for Australian litigation and advocacy, describes the operations of the Tobacco Institute of Australia (TIA). From 1978 to 1997 the TIA was the primary voice for tobacco in Australia, and there is little information about it in the published literature. The TIA was a National Manufacturers Association (NMA) - a group representing joint industry interests, creating a united front and lower public profile for individual manufacturers. The TIA co-existed with, predated, and was linked to many similar NMAs worldwide, thus an understanding of the TIA may inform understandings of the role and functions of other NMAs.

In addition to providing a brief history of the TIA, this paper will focus on the interconnectedness of the tobacco industry and the TIA's role in facilitating it. Interconnectedness on non-competitive issues is not confined to tobacco: many industries have lobby groups or national associations representing their interests to decision makers and the public. But the interconnectedness of the tobacco industry takes on special significance in light of the harmfulness of its product to consumers, and the industry's concerted attempts to undermine the credibility of information provided to smokers by public health and medical professionals over the last half century.

Interconnectedness is a key issue in Australia for two reasons. Firstly, there is a tendency in Australian advocacy to conflate "the industry" rather than examining individual manufacturers, a valid focus only if the manufacturers were clearly working together. More significantly, the structure of the Australian industry makes interconnectedness an important issue. In the USA the industry is domestic and has historical, financial, cultural, and manufacturing roots deep in American soil. This is not the case in Australia, making it vitally important to understand the relationship between the Australian and international industries. Tobacco companies operating in Australia move onto and, more frequently, off of the Australian Stock Exchange, as a result of mergers and takeovers; genuinely Australian tobacco companies have barely existed, most operators being part of international conglomerates. Corporate governance is not straightforward; control of basic functions such as marketing shift from global to local and back. Despite this, when confronted with international legal findings the local manufacturers have been known to claim that they are "completely different" to overseas operators, ${ }^{1-3}$ a proposition largely untested in Australian courts as litigation is in its infancy. All of these factors make it impossible to presume anything about the relationships between Australian tobacco manufacturers and other organisations.

As evidence mounts from the tobacco industry documents, mostly regarding conduct in the USA, advocates, lawyers, politicians, and others in Australia thus rightly ask: what has that got to do with us? The operation of the TIA is one piece in the puzzle of the relationships of the Australian tobacco manufacturers to one another and to their international parents and associates. Our interest in the TIA centred on questions relating to connectedness, cooperation, and control within the international and local industry. These included:

- Was the Australian industry aware of the international developments in key areas such as smoking and health?

- If so, did the TIA play a role in fostering this awareness?

- Did the TIA connect the international industry to the local industry and if so, how?

- Did local cigarette manufacturers cooperate through the TIA to mislead Australian consumers on smoking and health matters?

\footnotetext{
Abbreviations: AFCO, Australian Federation of Consumer Organisations; AHA, Australian Hotels Association; BAT, British American Tobacco; ETS, environmental tobacco smoke; ICOSI, International Committee on Smoking Issues; NMA, National Manufacturers Association; PML, Philip Morris (Australia) Ltd; SHB, Shook Hardy and Bacon; TIA, Tobacco Institute of Australia; USTI, US Tobacco Institute; WA, Western Australia
} 
An understanding of the relationships between local and international manufacturers is vital for advocacy, lobbying, and interpretation of history. In addition, the Australian Trade Practices Act 1974 limits cooperation between industry competitors, increasing the potential usefulness of this information in Australian litigation.

\section{METHODS}

Data for this paper came from primary and secondary document sites on the world wide web arising from litigation in the USA: ${ }^{4}$ primary sites of the manufacturers, ${ }^{5}$ the Council for Tobacco Research ${ }^{6}$ and the US Tobacco Institute, ${ }^{7}$ and the secondary sites of Tobacco Documents Online (Bliley, BC, Health Canada, and Guildford Miscellaneous collections), ${ }^{8}$ the Canadian Council for Tobacco Control site, ${ }^{9}$ the British Columbia Ministry of Health Services site, ${ }^{10}$ and the Center for Disease Control and Prevention Guildford site. ${ }^{11}$ The first search, of all sites, used the string ("tobacco institute of australia"|"tia"|"ti of aus" ${ }^{* \prime} \mid$ "ti aus*"| "tob* inst* aus" "tob* inst* of aus*"), resulting in 2917 documents. Leads identified from these documents, particularly individuals and projects, were followed up as appropriate, resulting in a further 1624 documents. 869 documents were abstracted: summaries are available on http://tobacco.health.usyd.edu. $\mathrm{au} /$ site/gateway/docs/index.htm

A descriptive account of the TIA's activities was constructed from these documents, and decisions about the relevance of documents were made with the above questions in mind. Further information on the research project's objectives and searching methods is available elsewhere. ${ }^{12}$

\section{RESULTS}

In 1975, as publicity about the health effects of smoking accelerated following the introduction of health warnings, Philip Morris (Australia) Ltd (PML) proposed that an Australian equivalent of the US Tobacco Institute was needed to "draw the line of fire away from the cigarette companies individually and collectively". ${ }^{13}$ The TIA was established in 1978 "in response to pressure ... for electronic advertising bans, an Industry Assistance Commission Inquiry and the pressing need for industry coordination in relation to noncompetitive issues" ${ }^{\prime 14}$ Its objectives were:

- "to defend the industry's right to market its products without unwarranted restrictions in Australia

- to promote a better understanding by decision makers and the various Australian publics of the tobacco industry and its place in the national economy

- wherever possible, to gain recognition for the beneficial aspects of smoking

- to introduce a proper perspective on environmental hazards which have a detrimental effect on public health". ${ }^{15}$

Between 1978 and 1997 it pursued these via strategies including attacks on individuals and organisations making health claims; personal contact with politicians; third party strategy; the production of films, publications and public affairs resources; media liaison; paid advertising; litigation; nurturing industry friendly scientists and consultants; and making submissions to government inquiries. The TIA had three founding members: PML, Rothmans (Australia) Limited, and WD\&HO Wills (Australia) Limited. WD\&HO Wills (henceforth Wills) was the tobacco manufacturing subsidiary of AMATIL and part of the British American Tobacco (BAT) Group. RJ Reynolds, a US company that operated in Australia primarily via distribution and had the smallest market share, was a member only from 1980 to $1991 .{ }^{14}$

\section{FOUR SEASONS: AN ORGANISATIONAL HISTORY OF THE TIA}

The TIA's history can be divided into four chapters.

\section{Join hands for commercial freedom: 1978-1983: 5 years}

From 1978 to 1983, the TIA focused on networking, lobbying and publication, regarding advertising bans, environmental tobacco smoke (ETS), smoking and health, youth smoking, and the industry's economic contribution. Its inaugural director was Bryan Simpson, ex-chairman of the Australian Media Council, marketing director of the newspaper group Herald and Weekly Times Ltd, and friend of the industry. ${ }^{16}{ }^{17}$ He established the "TIA News Bulletin" to communicate industry positions; contacted politicians and bureaucrats; established a "tobacco action network"; and formed relationships with consultants. ${ }^{18-21}$ Although tobacco control advocates remember Simpson as less than incisive in public debate, * PMI felt that "the ability of the TIA to respond to the media ...improved consistently" under his leadership, ${ }^{22}$ and he went on to an international tobacco career. Brian Gapes succeeded Simpson in October 1982. Gapes was another industry friendly advertising man, with conservative political connections, and was former chairman of the Tobacco Products Advertising Council, a self regulatory body of the Advertising Federation of Australia. ${ }^{17}$ Gapes continued Simpson's relationship building and lobbying until his departure in 1983.

\section{Take no prisoners: 1983-1989: 6 years}

John Dollisson, TIA CEO from 1983-1987, was a strong personality, strategist, and media player with a dramatic flair, who claimed to have previously worked for government in a specialist statistical role. ${ }^{23}$ He was noticed internationally by the industry in 1983 when he led successful opposition to a tobacco advertising ban in Western Australia (WA). ${ }^{24}$ Dollisson's aggressiveness and breadth of focus is exemplified by his "casebook approach" to public relations: detailed, preemptive positions, developed in collaboration with the manufacturers during his appointment, which contained ideas, arguments, rationales, and means by which to attack proponents of tobacco control on a wide range of issues. ${ }^{25}$ Under Dollisson the TIA rapidly became "highly competent and effective" in the eyes of the international industry. ${ }^{26}$ By 1984 he was on the international industry's speaking circuit, ${ }^{27}$ and by 1986, RJR was concerned about the continued effectiveness of the TIA when he moved on. ${ }^{28}$

Dollisson regularly and aggressively advanced the industry's arguments in public, arguing, for example, that active and passive smoking were not harmful, that nicotine was not addictive, and that advertising did not influence nonsmokers, particularly children. Ironically, the TIA's Achilles' heel was Dollisson's aggressive advocacy. In July 1986 he placed an advertisement in the national press entitled "A message from those who do...to those who don' $t^{\prime \prime 29}$ in which he claimed "there is little evidence and nothing which proves scientifically that cigarette smoke causes disease in nonsmokers" ${ }^{30}$ Early in 1987, Dollisson placed a "followup" ad for the TIA, as demanded by the Trade Practices Commission, which among other things stated that the TIA did not accept that their original advertisement was misleading. ${ }^{31}$ This action triggered a six year legal war between TIA and the Australian Federation of Consumer Organisations (AFCO), at substantial cost to the TIA. ${ }^{32}$

Blair Hunt was headhunted to replace Dollisson when he moved to PMI in 1987. During Hunt's two year stay the TIA

*Gray N. Interview. Personal communication to Chapman S, Carter S, Bryan-Jones K. Sydney: 29 Nov 2002. 
began a long decline in influence. A fight against the 1987 Victorian Tobacco Control Bill, in cooperation with Dollisson at PMI, and using many of the tactics from 1983 in WA, was spectacularly unsuccessful. In an industry newly preoccupied with legal liability, perceptions of Dollisson's strategies seem to have changed. In a key meeting between manufacturers, TIA, and counsel in September 1987, the TIA was warned that it was becoming increasingly difficult to develop witnesses on the health issue, that hypocrisy on the industry's part could work against it in court, and that new tactics were needed, concluding: "it is essential that the industry be right in everything it says... Spokesmen for the industry must be cautious, correct and credible. They should ensure that what is said or done does not undercut product liability defence." "33 In 1989 a Brown and Williamson executive wrote: "I am extremely leery of any project on which John Dollisson is the PM representative... since he is not well controlled by New York." ${ }^{134}$ Hunt left early in 1989, narrowly escaping the beginning of a troubled five years for the TIA.

\section{Lick the wounds, send in the lawyers: 1989-1994: 5 years}

Richard Mulcahy took over from Blair Hunt in 1989. Mulcahy was a former director of the Wrigley Gum Company with more than 15 years public affairs management experience, including work for the US embassy in Canberra and the premier of Victoria, and as CEO of the NMA for another controversial industry, the Confectionary Manufacturers of Australia. ${ }^{35}$ Mulcahy disappears from industry documents in mid 1990, about the same time that he began a career with the Australian Hotels Association (AHA), where he remained national executive director until June 2003. Although there is no documentary evidence that this was a deliberate strategic move, ETS in hospitality settings was becoming a major preoccupation of the Australian tobacco industry, and the AHA has supported the tobacco industry consistently on ETS issues ever since. Mulcahy's replacement, John St Vincent Welch, and his deputy and successor Reinier Jessurun both fell quickly from favour with the manufacturers, ${ }^{36-38}$ and Jerome Mostyn, Jessurun's replacement and a long time BAT man, appears to have been terminated after only six months following a political misdemeanour. ${ }^{39}$

From 1989 to 1994 the TIA was active, with a \$A19 508687 budget between 1991-94, ${ }^{14}$ but it was a difficult, disjointed, and transitional period, during which Dollisson's headstrong, confident legacy was overturned by defeat and legal caution. In large part, this was due to AFCO vs. TIA. On 7 February 1991 Justice Morling decided that the TIA "had engaged in conduct that was misleading or deceptive" and banned the TIA from speaking publicly on ETS. ${ }^{40}$ On appeal the injunction was lifted, but the court granted a declaration that the advertisement was misleading and deceptive contrary to the Act and the TIA were ordered to pay a large proportion of AFCO's costs. The industry has consistently attempted to represent this as an overturning of Morling's decision, but it was not: the substance was unchallenged. Due largely to the case, the TIA's credibility within the industry hit an all time low and control shifted to the local and international manufacturers and their counsel, as evidenced by a 1992 Philip Morris Companies NY directive that "any future statements by TIA on this subject will be carefully reviewed by the lawyers, so that the problems inherent in the 1986 ad can be avoided". ${ }^{42}$

\section{Last days: 1994-1997: 3 years}

Donna Staunton was the TIA's general counsel from the early 1990s and before that was senior associate for the industry's
Australian lawyers, Clayton Utz. By December 1993 she was made the TIA's CEO, and appointed a team of lawyers as staff, further strengthening the legal character and control of the organisation. Instructed explicitly by the manufacturers' lawyers, ${ }^{43}$ she reintroduced dynamism to the TIA, undertaking consultations with local and international counsel, organising tours of legal experts, developing formal cleared position statements, undermining the National Health and Medical Research Council's report on ETS, and participating in a 1994 Industry Commission inquiry. Under her guidance the TIA was, according to PML, in its "best shape for years... and operating effectively...12 months ago ignorance and distortion [in public affairs matters in Australia] were virtually universal. Amongst the chief causes of this appalling situation was the muzzling of our side of the debate and the virtual paralysis of the Tobacco Institute which followed the iniquitous Morling decision... Following a reversal of Morling on appeal, the industry and a newly revitalised Tobacco Institute in particular are involved in a broad debate which is at least partly on our agenda." ${ }^{\prime 4}$

By January 1995 Staunton had moved to Philip Morris Australia as director of corporate affairs, and after only three months she was promoted to become head of PMI Corporate Affairs for the region. She was replaced by another experienced tobacco executive, Brendan Brady, but not for long. Wills resigned from the TIA by mid 1996, and Brady not long afterwards, to be replaced briefly by his deputy and the TIA's general counsel, Adrian Lucchese. ${ }^{45}$ The public face of the organisation seems to have died a quiet death sometime in $1997,{ }^{46}$ although it still exists on paper.†

\section{THE INTERCONNECTEDNESS OF THE INDUSTRY}

Industry documents suggest several relevant forms of interconnectedness: links between local manufacturers, links formed by individuals, links to international tobacco organisations, legal links, and information links.

\section{Links between local manufacturers}

It is clear from the documents that the TIA linked local manufacturers from its inception, and that the level of cooperation between the manufacturers fluctuated over time. Cooperation was not new: the manufacturers had set up an "ad hoc committee" to manage public affairs aspects of the "health question" in 1969, ${ }^{47}$ and according to Andrew Whist, vice president of corporate affairs at PMI: "historically, the industry [was] better organized in Australia than just about anywhere else...because of the three way market split, it [was] much easier to arrive at a consensus." 48 Australian manufacturers made agreements on public positions and were expected to stick to them, ${ }^{49}$ and the TIA enhanced this cooperation throughout the 1980s, when "company support for the [TIA was] very strong, including the secondment of company personnel for lobbying representational activities", 50 "the [TIA was] dynamically led by the companies", ${ }^{51}$ and PML, at least, saw itself as "directing" the TIA. ${ }^{52}$

Cooperation was a hallmark of the 1980s, but contest for control is more evident in documents from the early 1990s. In the TIA's dark days, Reynolds left and the remaining members lost faith. Wills thought the TIA's structure was "ineffective and unmanageable and therefore not serving Wills' interests", that the organisation typically failed to foresee coming disasters for the industry, and that replacement staff would need "a degree of maturity, which has not been evident at the TIA for some time...given our recent lack on 23 November 2001. 
of success with outsiders". ${ }^{53}$ In May 1993, a Philip Morris executive wrote: "we should question the assumption that there be an industry voice either collectively or through the TIA. While consistency and cooperation among [manufacturers] is essential, one of the challenges facing us is the negative baggage of TIA and the correct strategy for successfully co-opting our two competitors. I am presently inclined to the view that PM should fully develop its strategy and its implementation before we fully involve the other companies." ${ }^{54}$ Cooperation may have been hampered by individual manufacturers' desires to "co-opt" the TIA's agenda and to ensure industry consistency on their own terms, as exemplified by concerted and unsuccessful TIA attempts over several years to facilitate industry consensus on active smoking and health. This may also have contributed to Wills' departure from the TIA in 1996.

The manufacturers were undoubtedly divided by local price wars and tax increases, ${ }^{55} 56$ but the documents also suggest a more profound international power struggle, reflected at the TIA: PM were in power, and BAT were revolting against the implications of that hegemony. By 1990 PMI were acting as general counsel to the international tobacco organisation INFOTAB $^{57}$ and from Staunton's appointment onwards the TIA also appears to have been increasingly aligned with PML. PML explained Wills' defection as consistent with British American Tobacco's increasing independence, resistance to being involved in "PM dominated industry initiatives", and intention to be "in the same shape that Philip Morris is in currently - that is, to be aggressive, out in front, to be the industry leader". ${ }^{58}$

Despite the evident tension in the 1990s, the manufacturers' counsel were all closely involved in the TIA's affairs, the TIA was active on the manufacturers' behalf, and the TIA's policy was that it "should not and would not pursue any course of action without the support of the three [manufacturers]". ${ }^{59}$ Since the dissolution of the TIA, there have been a number of cooperative industry activities launched in Australia, notably on youth smoking, suggesting that, at least on some issues, the corporate affairs managers at the major manufacturers have been able to rediscover some common ground.

\section{People links}

Individual staff linked the local and international manufacturers and local and international organisations as they moved from one position to the next. Executives moved in and out of the TIA from advertising, politics, law firms acting for tobacco, and particularly the local and international manufacturers and tobacco lobby groups. Bryan Simpson was a consummate networker, linking the TIA to US manufacturers, the US Tobacco Institute (USTI), US consultants including Council for Tobacco Research stalwart Leonard Zahn in New York, the International Committee on Smoking Issues (ICOSI), and INFOTAB. After time overseas he brought his experience back to Australia, standing in as a temporary director or lobbyist when the TIA was under pressure into the mid 1990s. Mostyn and Brady brought experience of working for BAT and lobbying in the UK to the TIA; Ken Pimblett worked for both the TIA and RJR Australia; and John Gonsci worked for Rothmans Australia and acted as chair of the TIA's legal committee. Donna Staunton, in addition to her knowledge from working for Clayton Utz, may have linked the TIA most strongly to Philip Morris: she met regularly with Henry Goldberg, the managing director of Philip Morris Australia, and sent reports to Goldberg which do not appear to have been copied to other directors as one would expect. ${ }^{60}{ }^{61}$ Greg Fowler from Shook Hardy and Bacon (SHB), US based counsel to the international industry, worked on TIA business in Melbourne in the 1990s, reporting back to SHB.

It is not unusual for executives to move between organisations within a field in the course of their career: the significance of these connections is as additional evidence that the business of the TIA overlapped with that of the local and international industry.

\section{INFOTAB and the USTI: the 1980s}

The TIA also linked the local companies to international tobacco organisations, although these relationships changed over time. In the 1980s both the old and established USTI and INFOTAB, an international NMA support organisation, were strongly linked to the TIA. ICOSI was established in the late 1970s and renamed INFOTAB in 1981. INFOTAB was a hub for tobacco companies, leaf dealers, and in particular about 30 NMAs like the TIA, many of which INFOTAB had actively "planted". ${ }^{62}$ The development of this network was a formal, international agreement by the industry to cooperate on noncompetitive issues; a deliberate collusion against the best interests of the consumer to protect industry profits. INFOTAB and the TIA were in constant contact, keeping the TIA updated on issues, the industry and its opponents worldwide. Simpson had also negotiated a relationship of "direct contact" between the TIA and the USTI when the TIA was founded, ${ }^{63}$ and nurtured the link into the 1980s. New TIA directors routinely visited the USTI for orientation, and the institutes swapped tactics and information.

\section{Legal control: the 1990s}

In contrast to the cooperative 1980s, in the 1990s many TIA staff were lawyers, and the TIA was directed by a triumvirate: a committee of the in-house counsel of the manufacturers; Clayton Utz, the TIA's counsel; and most importantly, SHB in Kansas. Legal involvement in the TIA was not new: Simpson corresponded regularly with SHB in the early 1980s, and Dollisson had, ironically, been aware of nascent product liability threats in 1985, retaining a medical advisor, Dr Allan Crawford, a barrister, Barry O'Keefe, and a legal firm, Clayton Utz, sending them all overseas to be briefed by the international industry and their counsel. ${ }^{64}{ }^{65}$ In 1988 the TIA began a document management programme to prepare for potential product liability claims. ${ }^{52}$

In 1990 a solicitor from Baker \& McKenzie was appointed as staff legal manager, and the Tobacco Institute Legal Committee was established. ${ }^{66}$ Importantly, members of this committee were senior management and counsel from the member manufacturers (along with TIA staff): Phil Francis and Judy Hargrave from PML; Martin Riordan and John Carroll from Wills; and Peter Alexander, John Gonczi, and Peter Malecki from Rothmans. ${ }^{67}$ From this point on the manufacturers and their counsel were undoubtedly monitoring and clearing the TIA's work, and legal involvement intensified exponentially as AFCO brought the international industry and their lawyers deeper into the TIA's affairs. Tony Andrade, a senior London based PMI lawyer, devoted substantial time to the AFCO case, witness development occurred overseas, and attorneys' bills were covered by PML, Rothmans, and Reynolds despite the fact that they were not under trial (only the TIA was sued).$^{57}$ In 1991 Clayton Utz renegotiated existing retainers for local silks Jeffrey Sher QC, Richard Stanley QC, and Joseph Santamaria QC, an increasingly expensive proposition, but necessary in the face of the increased "threat" of litigation. ${ }^{68}$

It appears that TIA management were not always part of the decision making on this increased legal involvement. Early 1990s documents show direct correspondence between the manufacturers' counsel regarding TIA business, not always copied to TIA staff. ${ }^{69}$ 
This cumulating legal control reached a deciding point in April 1991, when Chuck Wall (PMI) wrote two memos to Judy Hargrave, counsel to PML. In the first he makes plain that PMI is to "keep a hands-on involvement with the AFCO case, including the approval of any briefs that are submitted, assuming we decide to appeal".$^{70}$ In the second, which, importantly, is expressed as the joint view of all of the international tobacco companies, he essentially insists that from that point on, clearance should be managed by the Legal Committee (that is, the manufacturers' counsel), not Clayton Utz alone; and that Bob Northrip from SHB Kansas should take control. "We have a great deal of confidence in Bob Northrip on all issues relating to smoking and health. Therefore, we have asked Bob to work with the Institute, the committee and Clayton Utz, to see that there is coordination, and that proper action is taken." ${ }^{171}$ Northrip appears to have taken a leading role on vital issues from that point. He finalised the brief for the AFCO vs TIA case with the member companies, he made visits to Australia, and Clayton Utz were required to respond to his advice. ${ }^{72}{ }^{73}$

In 1992 another SHB lawyer, Greg Fowler, also became involved, initially coordinating TIA smoking and health work (previously done in-house or at Clayton Utz) from Kansas, ${ }^{74}$ and then in January 1993 moving to Australia for approximately a year. ${ }^{75}$ Fowler seems to have been based at Philip Morris but to have worked substantially on TIA projects, and to have reported to Northrip at the SHB Kansas home base. ${ }^{76}$ Despite the tensions, the TIA's actions were certainly controlled by the local and international manufacturers and their counsel in the 1990s.

\section{Information links}

This form of interconnectedness is particularly important in that it shows that the TIA was intimately informed of international developments in smoking and health research. There are no grounds for the Australian industry arguing that they were somehow unaware of the international research on smoking and health: its continuing public recalcitrance was not due to ignorance, but a deliberate attempt to protect industry interests. Information was supplied first by the USTI/INFOTAB links, and then by the legal links. INFOTAB and the USTI operated substantial and constantly updated databases of information in the 1980s and early 1990s, providing the TIA with media monitoring; copies of published papers and reports; catalogues of NMA resources and programmes for implementation; intelligence from NMAs and consultants on health conferences and organisations including the World Health Organization; reports of international legal activity; and coordinated responses to international public health activities. ${ }^{50} 77$

For at least five years in the 1980s, an information officer was employed by the TIA solely to manage the deluge of material. Because many NMAs had a similar officer, INFOTAB ran an "internal meeting for documentalists, librarians and information officers" in Brussels in 1985, ${ }^{78}$ at which Simpson declared: "like a competent army, the Tobacco Industry needs first class intelligence, and on a world wide basis INFOTAB is endeavouring to supply this vital need to its members, its associations, and lead companies...we at INFOTAB carefully sift all the material available and include it in the resources available to you. We also encourage as much science as possible which offers a balanced view on the smoking issue." ${ }^{\prime 79}$ This highlights an important role performed by these information sourcesactively seeking and making accessible the tiny subset of research which supported the industry's views, as illustrated by a TIA request to the USTI for "articles refuting SG report or UK Royal College of Physicians report". ${ }^{80}$ The exchange was bilateral: the TIA provided resources to INFOTAB, including personnel to present at global and regional meetings, and information for the extensive INFOTAB database, particularly during Dollisson's appointment.

INFOTAB closed in 1990-91, and as legal involvement increased across the 1990s, SHB provided information and education to the TIA in place of INFOTAB, as well as reviewing and clearing TIA publications and advising Clayton Utz. By 1994, SHB appear to have been serving NMAs and non-PM companies worldwide, undertaking tasks such as preparing talking points, ${ }^{81}$ and running "smoking and health" seminars for BATCo, attended by the TIA. ${ }^{82}$

\section{CONCLUSIONS}

The TIA, like any organisation, was not static. Its perceived effectiveness, the personalities at the helm, its control base, and its culture changed substantially over its 19 year life. The TIA's early days established important networks and paved the way for its heyday in the early-mid 1980s, when it presented a united front and won battles, inspired local manufacturers to cooperate, and connected Australia to the admiring international tobacco family. As a direct result of the AFCO vs TIA case, it sank into disrepute and disarray for five years. Takeover by the industry's lawyers and the elevation of Donna Staunton to CEO led to another active period in the early 1990s, when united industry positions were presented aggressively to decision makers and the public despite internal power struggles. Although the TIA still exists on paper, functionally it appears to have been replaced around 1997 by direct manufacturer cooperation on shared corporate affairs management issues.

The focus of this paper has been the issue of interconnectedness: between local manufacturers and between Australian and international industry bodies. Links between local manufacturers, links formed by individuals, links to international tobacco organisations, legal links, and information links have been explored, all with the four questions posed in the introduction to this paper in mind.

It is clear that the TIA was comprehensively informed, first by INFOTAB and USTI, and then by the industry's international counsel, of developments in international research, advocacy, policy, and litigation. The close involvement of the local manufacturers in the TIA, through individuals and through organisational structures, provided a conduit for this information to be distributed. The TIA also actively sought dissenting opinion which they digested and made available to the manufacturers to assist them in perpetuating deception on active smoking and other issues, a task which mirrored and was supported by the efforts of their international informants. The local industry cannot claim ignorance of the science.

It has also been shown that the TIA linked the local to the international industry, in addition to specific links between local manufacturers and their parent companies. The local industry cannot therefore claim isolation from the international industry. In the 1990s, in particular, the local and international counsel of the industry appears to have been essentially running the TIA's affairs on all but the most routine matters.

Finally, there is no doubt that the manufacturers intended to cooperate through the TIA, and that the objects of their cooperation (such as producing a statement on smoking and health to undermine medical opinion) were not in the best interests of Australian consumers. Nigel Gray, leading Australian tobacco control advocate, has noted that the TIA always presented a united front, and may have done its best work behind closed doors, in its lobbying of decision makers.‡

$\ddagger$ Gray N. Interview. Personal communication to Chapman S, Carter S, Bryan-Jones K. Sydney: 29 Nov 2002. 


\section{What this paper adds}

Australia is widely considered to be a bellwether country in tobacco control, and anecolotally the Tobacco Institute of Australia (TIA) has been considered an internationally significant National Manufacturers Association (NMA). However the TIA's history, role, and activities, and the relationships between the TIA and local and international tobacco organisations, have had little attention in the published literature.

This study examines the history of the TIA and the connections it facilitated: links between local manufacturers; links through individuals who played multiple roles; links to international tobacco organisations; legal links; and information links. It demonstrates that the TIA's conduct was the responsibility of local and international manufacturers and their counsel, providing context for Australian tobacco document research and history, and important evidence for advocacy and litigation in Australia.

Internally, industry relationships appear to have been variably successful. Cooperation was apparently easier in the aggressive and confident 1980s, whereas post-AFCO, when legal involvement intensified and competitive issues were pressing, private dealings appear to have sometimes been fractious.

Specific details of TIA campaigns arising from this project will be provided in other papers, in the context of particular policy issues. These papers should be read in light of the evidence presented here, which leaves no doubt that the TIA was led by the manufacturers, and thus responsibility for the actions of the TIA, including their deceptive public statements, can be laid squarely at the manufacturers' feet. It is hoped that this will assist in advocacy, lobbying, litigation, and interpretation of history, and will lay to rest any Australian industry attempts to distance themselves from the workings of the international industry.

\section{ACKNOWLEDGEMENTS}

Thanks to Simon Chapman and the reviewers for comments and Fiona Byrne for information management. The research reported in this paper was supported by grants from the National Health and Medical Research Council (2001-2003 \#153857) and the US National Institutes of Health (2001-2005 \# R01 CA87110-01A1).

\section{REFERENCES}

1 Harris T. US smokes not like ours. The Weekend Australian (Sydney, NSW) 12 Jul 1997:7.

2 WD \& HO Wills. WD \& HO Wills Holdings-Chairman's Address. 17 Apr 1997. Philip Morris. Bates No. 2072527522/7525. http:// legacy.library.ucsf.edu/tid/vtc42c00

3 Lipari K. Rothmans warns on profit. 12 Jul 1997. Philip Morris. Bates No. 2065329380. http://legacy.library.ucsf.edu/tid/qdp63c00

4 Malone RE, Balbach ED. Tobacco industry documents: treasure trove or quagmire? Tobacco Control 2000;9:334-8.

5 Tobacco manufacturers' document websites. http://www.pmdocs.com-bin/ rsasearch.asp; http://www.bw.aalatg.com/public.asp; http:// www.lorillarddocs.com/cgi-bin/rsasearch.asp; http://www.rjirtdocs.com/ rirtdocs/index.wmt?tab = home

6 Council for Tobacco Research document website. http://www.ctr-usa.org/ $\mathrm{ctr} /$ index.wmt? tab = home

7 Tobacco Institute document website. http://www.tobaccoinstitute.com/cgibin/Rsasearch.asp

8 Tobacco Documents Online. Smokescreen Corporation. http:// tobaccodocuments.org/

9 Canadian Council for Tobacco Control tobacco documents site. http:// www.ncth.ca/Guildford.nsf

10 British Columbia Ministry of Health Services tobacco documents site. Accessed 13 Mar 2003. http://www.moh.hnet.bc.ca/cgi-bin/ guildford_search.cgi

11 Center for Disease Control and Prevention Guildford tobacco documents site. Accessed 13 Mar 2003. http://www.cdc.gov/tobacco/industrydocs/ index.htm
12 Chapman S, Byrne F, Carter SM. "Australia is one of the darkest markets in the world": the global importance of Australian tobacco control. Tobacco Control 2003;12(suppl III):iii 1-3.

13 Maxwell H. Philip Morris Limited five year management plan 1976-80, Part II. Mar 1975. Philip Morris. Bates No. 2500012700/2880. http:// legacy.library.ucsf.edu/tid/cpi42e00

14 Philip Morris. Industry issues. 2 Oct 1996. Philip Morris. Bates No. 2504081924/2024. http://legacy.library.ucsf.edu/tid/uwy45d00

15 Covington M. Background information for visit of Mr. Bryan Simpson, Director Tobacco Institute of Australia. 21 Sep 1978. Philip Morris. Bates No. 1000219634/9635. http://legacy.library.ucsf.edu/tid/zsd84e00

16 Whist A. [Letter to H. Maxwell]. 20 Mar 1975. Philip Morris. Bates No. 2024258541/8544. http://legacy.library.ucsf.edu/tid/ufl98e00

17 Whist A. Bryan Simpson and Brian Gapes. 6 Oct 1982. Philip Morris. Bates No. 2023084648/4649. http://legacy.library.ucsf.edu/tid/zya44e00

18 Tobacco Institute of Australia. TIA news bulletin issue no. 2. May 1979. Philip Morris. Bates No. 2501159470/9473A. http://legacy.library.ucsf.edu/tid/ hwt22e00

19 Tobacco Institute (US). The Tobacco Institute College of Tobacco Knowledge student profiles. Sep 1980. Lorillard. Bates No. 81514938/4950. http:// legacy.library.ucsf.edu/tid/uek13c00

20 Simpson B. [Letter to L.S. Zahn]. Tobacco Institute of Australia. 11 Aug 1981 The Council for Tobacco Research. Bates No. HK0947052/7052. http:// legacy.library.ucsf.edu/tid/cvplaa00

21 Carter SM. From legitimate consumers to public relations pawns: the tobacco industry and young Australians. Tobacco Control 2003;12(suppl III):iii71-8.

22 Philip Morris International. 1981 Corporate Affairs status report. 1981. Philip Morris. Bates No. 2025881685/1708. http://legacy.library.ucsf.edu/tid/ did81f00

23 Dollisson J. Presentation by John Dollisson, Chief Executive Officer of the Tobacco Institute of Australia Limited, on Advertising and Health at the Hearing Meeting of the Broadcasting Review Board at Urban Council Chambers, Hong Kong on 9 January 1985. Tobacco Institute of Australia. 9 Jan 1985. Philip Morris. Bates No. 2504063712/3718. http:// legacy.library.ucsf.edu/tid/pzv19e00

24 Corti A. Tobacco advertising: a public debate between government and industry. INFOTAB. 19 Jan 1984. Brown \& Williamson. Bates No. 699100966/0967. http://legacy.library.ucsf.edu/tid/uho01f00

25 Tobacco Institute of Australia. Casebook arguments. May 1986. Philip Morris. Bates No. 2501456347/6356. http://legacy.library.ucsf.edu/tid/ clu22e00

26 INFOTAB. INFOTAB Board of Directors Meeting, Phoenix, October 29, 1984 29 Oct 1984. R.J. Reynolds. Bates No. 503880524/0585. http:// legacy.library.ucsf.edu/tid/lkb71d00

27 INFOTAB. INFOTAB/NMA Workshop, Brussels, October 8-11, 1984: list of participants. Oct 1984. Philip Morris. Bates No. 2023272783/2792. http:// legacy.library.ucsf.edu/tid/snt24e00

28 Marcotullio R. INFOTAB Board of Directors Meeting, Hamburg, November 4, 1986. 10 Nov 1986. R.J. Reynolds. Bates No. 516650654/0656. http:// legacy.library.ucsf.edu/tid/sxu82d00

29 Tobacco Institute of Australia. A message from those who do... To those who don't. Jul 1986. Philip Morris. Bates No. 2024986472. http:// legacy.library.ucsf.edu/tid/ffy46e00

30 Parrish S. Smoking and health litigation. 21 Aug 1990. Philip Morris. Bates No. 2024946097/6106. http://legacy.library.ucsf.edu/tid/qva77e00

31 Dollisson J. A follow-up to A message from those who do...to those who don't. Jan 1987. Philip Morris. Bates No. 2023582173. http:// legacy.library.ucsf.edu/tid/dsb98e00

32 Dennis D. The Australian Federation of Consumer Organisations Inc. vs. The Tobacco Institute of Australia 12 Feb 1991. Philip Morris. Bates No. 2501050820/0829. http://legacy.library.ucsf.edu/tid/qei49e00

33 Tobacco Institute of Australia. Meeting between legal counsel representing TIA and representatives of the tobacco industry, Tuesday, 8th September 1987. 15 Sep 1987. R.J. Reynolds. Bates No. 515777353/7355. http:// tobaccodocuments.org/bliley_rir/515777353-7355.html (Accessed 30 Jan 2003)

34 Humber T. Asian ETS project. 23 Mar 1989. Brown \& Williamson. Bates No. 680709429. http://legacy.library.ucsf.edu/tid/vfp33f00

35 Chilcote S. Remarks Samuel D. Chilcote, Jr. INFOTAB Group Session, Wednesday, October 18, 1989, Hong Kong. 18 Oct 1989. Tobacco Institute. Bates No. TIMN0317213/7239. http://legacy.library.ucsf.edu/tid/ cnu52f00

36 Jessurun R. [Memo to G. Watson, J. Devine, J. King]. Tobacco Institute of Australia. 1 Jul 1991. Philip Morris. Bates No. 2504085777A. http:// legacy.library.ucsf.edu/tid/twi29e00

37 Gonczi J. Prof. Richard Tweedie-Education Seminar 16-17 July 1991 Rothmans Holdings Limited. 4 Jul 1991. Philip Morris. Bates No. 2504203132. http://legacy.library.ucsf.edu/tid/xfn32e00

38 Staunton-Mayne D. TIA AFCO redrafted Win scenario. Tobacco Institute of Australia. 5 Aug 1992. Philip Morris. Bates No. 2504075726. http:// legacy.library.ucsf.edu/tid/dpk02a00

39 Bacon D. [File note: Teleconference call with M. Riordan-Wills Australia re: developments on labelling issue]. 25 Jun 1993. British American Tobacco Company. Bates No. 304030342. http://tobaccodocuments.org/ health canada/01200282.html (Accessed 30 Jan 2003).

40 Hargrave J, Crampton W. Tobacco Institute of Australia Limited at Australian Federation of Consumer Organisations Inc. 7 Feb 1991. Philip Morris. Bates No. 2021284752 . http://legacy.library.ucsf.edu/tid/ilh98e00

41 Chapman S. Australian court rules that passive smoking causes lung cancer, asthma attacks and respiratory disease. BMJ 1991;302:943-5. 
42 Bring M. Litigation victory-Australian ETS case. 17 Dec 1992. Philip Morris. Bates No. 2023005322/5324. http://tobaccodocuments.org/bliley_pm/ 23955. html (Accessed 30 Jan 2003).

43 Staunton-Mayne D. TIA ats AFCO-experts. Tobacco Institute of Australia. 23 Jul 1992. Philip Morris. Bates No. 2023241376. http:// legacy.library.ucsf.edu/tid/xjn87e00

44 Goldberg H. 1994 second revised forecast presentation, June 1994. New York. May 1994. Philip Morris. Bates No. 2504204001/4063. http:// legacy.library.ucsf.edu/tid/ygn32e00

45 Tobacco Institute of Australia. Court finds NHMRC acted improperly: media release. 20 Dec 1996. Philip Morris. Bates No. 2063834377/4378. http:// legacy.library.ucsf.edu/tid/qti32d00

46 Sweet M. Tobacco companies try to sow seeds of doubt. Sydney Morning Herald 6 Feb 1998. Philip Morris. Bates No. 2063792860/2861. http:// legacy.library.ucsf.edu/tid/hdq87d00

47 Philip Morris (Australia) Limited. Minutes of Philip Morris (Australia) Limited directors' meeting held on 1 August 1969. 1 Aug 1969. Philip Morris. Bates No. 2015047959/7960. http://legacy.library.ucsf.edu/tid/snq34e00

48 Whist A. [Memo to R.W. Murray]. 17 Apr 1984. Philip Morris. Bates No. 20232731 19/3120. http://legacy.library.ucsf.edu/tid/uot24e00

49 Whist A. Reynolds activities in Australia. 3 Dec 1982. Philip Morris. Bates No. 2023023931/3932. http://legacy.library.ucsf.edu/tid/gix36e00

50 INFOTAB. INFOTAB Board of Directors Meeting, Brussels. 4 Apr 1984. Philip Morris. Bates No. 2024970720/0804. http://legacy.library.ucsf.edu/tid/ bds02a00

51 Simpson B. Review of the issues and INFOTAB's activities Mr. Bryan Simpson Secretary General, INFOTAB African Regional Workshop Harare, July 2224, 1985. INFOTAB. 22 Jul 1985. Tobacco Institute. Bates No. TIMN0333622/3641. http://legacy.library.ucsf.edu/tid/kjq52fo0

52 Dollisson J. 1988 Philip Morris Sales Conference 'Challenge of Change'. 23 Jan 1988. Philip Morris. Bates No. 2504202605/2619. http:// legacy.library.ucsf.edu/tid/rlj29e00

53 Bacon D. Australian visit. 1 Jun 1992. British-American Tobacco Company Bates No. 500020128/0133. http://tobaccodocuments.org/ guildford_misc/500020128-0133.html (Accessed 30 Jan 2003)

54 Philip Morris (Australia) Limited. 2RF presentation to W.H. Webb (elongated version - not presented). 27 May 1993. Philip Morris. Bates No. 2504200049/0081. http://legacy library ucsfedu/tid//fn32e00

55 Non-Smokers' Movement of Australia Inc. Non smokers' update, Issue 13, July 1996. NSMA 1996. http://www.nsma.org.au/update13.htm (Accessed 30 Jan 2003).

56 Non-Smokers' Movement of Australia Inc. Non smokers' update, Issue 14 September 1996. NSMA 1996. http://www.nsma.org.au/updatel4.htm (Accessed 30 Jan 2003)

57 Newson J. May 24, 1990 meeting in London. Shook, Hardy \& Bacon. 6 Jun 1990. Philip Morris. Bates No. 2023239673/9695. http:// legacy.library.ucsf.edu/tid/gnx45d00

58 Windholz E. Industry co-operation - BAT. 11 Jun 1996. Philip Morris. Bates No. 2076367377/7378. http://legacy.library.ucsf.edu/tid/obg56c00

59 Tobacco Institute of Australia. Draft project plan for ETS public smoking and credibility. 28 Jul 1993. Philip Morris. Bates No. $2504079120 / 9125$ http://legacy.library.ucsf.edu/tid/ipk02a00

60 Staunton D. [Letter to H. Goldberg]. Tobacco Institute of Australia. 16 Mar 1994. Philip Morris. Bates No. 2504200226/0229. http:// legacy.library.ucsf.edu/tid/emi29e00

61 Staunton D. Chief Executive Officer's report. Tobacco Institute of Australia. 11 May 1994. Philip Morris. Bates No. 2504200222/0224. http:// legacy.library.ucsf.edu/tid/dmj29e00
62 Simpson B. [INFOTAB 1985 Membership renewal letter to A.J. Stevens] INFOTAB. 25 Jan 1985. Lorillard. Bates No. 80418771/8772. http:// legacy.library.ucsf.edu/tid/rbh74c00

63 Covington M. Bryan Simpson's visit. 13 Sep 1978. Philip Morris. Bates No. 2010052115. http://legacy.library.ucsf.edu/tid/cjk68e00

64 Dollisson J. [Brief summary of resume for Dr Allan Crawford]. 20 Aug 1985. Tobacco Institute. Bates No. TI06390573/0574. http:// legacy.library.ucsf.edu/tid/lay30c00

65 Holtzman A. Product liability case in Australia. 14 Aug 1986. Philip Morris. Bates No. 2023270179. http://legacy.library.ucsf.edu/tid/rev36e00

66 Mulcahy R. Manager-Legal (TIA). Tobacco Institute of Australia. 18 Jan 1990. Philip Morris. Bates No. 2024966007/6008. http:// legacy.library.ucsf.edu/tid/sbl87e00

67 Hay K, Klotz S. TIA v AFCO-questions and answers. Tobacco Institute of Australia. 2 Apr 1992. Philip Morris. Bates No. 2023241403. http:// legacy.library.ucsf.edu/tid/fkn87e00

68 Travers R. Retainers of Melbourne counsel. Clayton Utz. 13 Aug 1991. Philip Morris. Bates No. 2023249165/9167. http://legacy.library.ucsf.edu/tid/ idn87e00

69 Gonczi J. [Fax to J. Hargrave]. Rothmans Holdings Limited. 9 Apr 1992. Philip Morris. Bates No. 2504085900. http://legacy.library.ucsf.edu/tid/ dwi29e00

70 Wall C. Lawyers for Philip Morris in Australia and the AFCO appeal. 1 Apr 1991. Philip Morris. Bates No. 2047723722/3724. http:// legacy.library.ucsf.edu/tid/gui57d00

71 Wall C. [Letter to J. Hargrave]. 15 Apr 1991. Philip Morris. Bates No. 2047723716/3717. http://legacy.library.ucsf.edu/tid/fui57d00

72 Clayton Utz. TIA - workplace smoking brochure. 11 Dec 1992. Philip Morris. Bates No. 2023241340. http://legacy.library.ucsf.edu/tid/sjn87e00

73 Northrip R. [AFCO case: proposed brief]. Clayton Utz. 23 Aug 1991. Philip Morris. Bates No. 2072965365. http://legacy.library.ucsf.edu/tid/ kdo95c00

74 Fowler G. Dr. Brendan Nelson's press release. Shook, Hardy \& Bacon. 24 Nov 1992. Philip Morris. Bates No. 2504085861/5862. http:// legacy.library.ucsf.edu/tid/log48d00

75 Whidden RG. Japan. 16 Dec 1992. Philip Morris. Bates No. 2500053642/ 3643. http://legacy library ucsfedu/tid/dna02a00

76 Shook Hardy \& Bacon. Work in progress-Greg Fowler. 18 Jun 1993. Philip Morris. Bates No. 2023248282/8286. http://tobaccodocuments.org/ bliley_pm/24213.html (Accessed 30 Jan 2003).

77 Tobacco Institute Information Center. Information Center [activities and usage report]. Sep 1990. Tobacco Institute. Bates No. TI14580508/0510. http:// legacy.library.ucsf.edu/tid/bij86d00

78 INFOTAB. Co-operation in Documentation for the Tobacco Industry: an international meeting for documentalists, librarians and information officers, March 26-27, 1985 and March 28-29, 1985: draft programme. 25 Mar 1985. Philip Morris. Bates No 100504963/4976. http://

tobaccodocuments.org/bc_moh/12624.html (Accessed 30 Jan 2003).

79 Simpson B. Dealing with controversy, how industry manages public issues: INFOTAB's role. INFOTAB. 26 Mar 1985. Tobacco Institute. Bates No. TIMN0333570/3575. http://legacy.library.ucsf.edu/tid/hiq52f00

80 Deegan C. T.I. newsletter no. 346, 5.12.83. 14 Dec 1983. Tobacco Institute. Bates No. TIMN0149823. http://legacy.library.ucsf.edu/tid/pyy82f00

81 Winokur M. Talking points. 4 Mar 1994. Philip Morris. Bates No. 2047316223/6224. http://legacy.library ucsfedu/tid/swh87e00

82 Clarke P. Smoking and Health Legal Training Session [BAT/TIA Seminar, January 17-19, 1994]. 21 Dec 1993. British American Tobacco Company. Bates No. 503107835/7838. http://tobaccodocuments.org/ health canada/02000389.html (Accessed 30 Jan 2003). 